\title{
Improvement of the thermal efficiency of autoclaved aerated concrete by black powder
}

\author{
Chanita Mano, Atthakorn Thongtha*, Somchai Maneewan, Chantana Punlek \\ Department of Physics, Faculty of Science, Naresuan University, Phitsanulok 65000 Thailand \\ *Corresponding author, e-mail: atthakornt@nu.ac.th
}

Received 9 Nov 2020

Accepted 13 Jun 2021

\begin{abstract}
This study is concentrated on improving the thermal efficiency of autoclaved aerated concrete (AAC) by incorporation of black powder as an additional component. Black powder is a waste product of the automotive refinishing industry in Thailand. The dynamics of heat transfer and the cooling load of air conditionings in four simulated houses with different wall materials (brick, cement block, AAC, and black powder AAC) were investigated. The results from the comparison of heat fluxes of the interior surfaces demonstrated that incorporated black powder significantly increased the thermal effectiveness of construction materials, as observed from the black powder AAC. In addition, it was demonstrated that the cooling load and the power consumption of air conditioning in the house with black powder AAC walls was reduced, and the power consumption was saved approximately $25.5 \%, 37.9 \%$, and 48.1\% compared with the commercial AAC, the brick, and the cement block houses, respectively. The black powder AAC provided the highest power consumption reduction.
\end{abstract}

KEYWORDS: autoclaved aerated concrete, heat flux reduction, building materials, insulation material, cooling load

\section{INTRODUCTION}

The global demand of electricity consumption in buildings increased from $26 \%$ in 1980 to $54 \%$ in 2010, and the increase has been predicted to be $84 \%$ in $2050[1,2]$. The steady increase of building energy consumption is due to the population growth, the modern society, and the quality of life enhancements. To achieve indoor thermal comfort in the tropical weather, the cooling and heating of the air conditioning system contributes to approximately $65 \%$ of the total building energy consumption [1-3]. A reduction in thermal accumulation and thermal transmission into the interior of buildings is an alternative solution for reducing the energy consumption demand of cooling load in buildings [4-8]. Wall insulation materials show significant potential in reducing cooling loads in the tropical climates $[8,9]$.

Autoclaved aerated concrete (AAC) is a kind of thermal insulation materials that can reduce energy consumption to approximately 50\% [10]. AAC is popular due to being lightweight with highly porous structure and higher thermal resistance, lower thermal conductivity, and faster curing process compared with traditional concrete [11-16]. Uses of industrial by-products and recyclable wastes in the production of AAC have been widely studied, in- cluding coal bottom ash [12], copper tailings and blast furnace slag [17], air-cooled slag [18], efflorescence sand and phosphorus slag [19], lead-zinc tailings [20], iron ore tailings [21], high calcium fly ash and natural zeolite [22], and siliceous crushed stone [23].

In 2016, Thailand ranked 12th in the global automotive industry [24]. During the polishing processes, enormous quantities of black powder waste are annually produced leading to a significant problem on environmental and human impacts, especially in the landfill step of disposal. To decrease the amount of waste and the environmental impact, black powder is considered to be used as a raw material in AAC production. However, the incorporation of black powder in AAC has rarely been investigated before [25]. In this study, the black powder AAC was used to construct house walls, which then compared with walls of three other houses built with commonly used building materials: (commercial) AAC, brick, and concrete block. The dynamics of heat transfer and the cooling load of air conditioning system were investigated using the four simulated houses with different wall materials. The temperature fluctuation and the cooling load of air conditioning system in individual houses under actual weather were also investigated and compared. 


\section{MATERIALS AND METHODS}

\section{Fabrication of black powder AAC}

AAC is made of aluminum ( $\mathrm{Al})$, anhydrite $\left(\mathrm{CaSO}_{4}\right)$, lime $(\mathrm{CaO})$, Portland cement, and fine sand (less than $90 \mu \mathrm{m}$ in size) with the proportion in percentage by weight of $0.06,1.64,11.94,12.43$, and 73.93 , respectively. Black powder of $20 \%$ by weight, replacing the same amount of fine sand, was incorporated into the mixture of AAC to fabricate black powder AAC. The main oxide compositions of the black powder sample were $64.6 \% \mathrm{SiO}_{2}, 23.4 \%$ $\mathrm{Al}_{2} \mathrm{O}_{3}, 4.5 \% \mathrm{Fe}_{2} \mathrm{O}_{3}, 2.2 \% \mathrm{CaO}, 1.0 \% \mathrm{MgO}, 0.3 \%$ $\mathrm{Na}_{2} \mathrm{O}$, and $1.2 \% \mathrm{~K}_{2} \mathrm{O}$. The powder was less than $90 \mu \mathrm{m}$ in size, which was similar to the size of fine sand [25]. The fabrication of black powder AAC was done at a manufacturer plant well supplied with testing equipment. All components were well mixed together with water, and the mixture was poured into a $20 \mathrm{~cm} \times 20 \mathrm{~cm} \times 100 \mathrm{~cm}$ mold. The mold was kept at $180-190^{\circ} \mathrm{C}$ under a pressure of 12 bars. The black powder AAC was cut to uniform blocks of $7.5 \mathrm{~cm} \times 7.5 \mathrm{~cm} \times 7.5 \mathrm{~cm}$ for further experimentations.

Compressive strength, density, water absorption, and thermal conductivity measurements

Some black powder AAC blocks were dried at $75^{\circ} \mathrm{C}$ for $24 \mathrm{~h}$ and then tested for the compressive strength following ASTM C1555-03a. Some were dried at $105^{\circ} \mathrm{C}$ for $24 \mathrm{~h}$ and tested for density and water absorption following ASTM C642-97. The thermal conductivity of the black powder AAC was analysed by the hot disk thermal constant analyzer (Hot Disk AB: TPS2500S)

\section{House construction}

As shown in Fig. S1, each house was basically designed and built for testing the actual use in the tropical climate. The wall of the four houses was individually constructed from four different materials: brick, concrete block, AAC, and black powder AAC. The brick, the cement block, and the AAC possessed a density of $1.80 \mathrm{~g} / \mathrm{cm}^{3}, 2.21 \mathrm{~g} / \mathrm{cm}^{3}$, and $0.61, \mathrm{~g} / \mathrm{cm}^{3}$ and the thermal conductivity of $0.473 \mathrm{~W} / \mathrm{m}^{\circ} \mathrm{C}, 0.519 \mathrm{~W} / \mathrm{m}^{\circ} \mathrm{C}$, and $0.157 \mathrm{~W} / \mathrm{m}^{\circ} \mathrm{C}$, respectively. Each house was $13.25 \mathrm{~m}^{3}$ in volume with four sides of walls. The walls, each with $5.52 \mathrm{~m}^{2}$ area, were $8 \mathrm{~cm}$ thick and coated with cement plaster. Both interior and exterior surfaces were unpainted. The roofing materials were concrete roof tiles with aluminum foil to reflect heat.
The inclination of the roof angle was $30^{\circ}$ to the horizontal plane. The ceiling was built with $1 \mathrm{~cm}$ thick gypsum board to prevent and reduce the thermal transmission through the roof. A wooden door, $0.84 \mathrm{~m} \times 1.84 \mathrm{~m}$, was installed on the south side of the house; and a glass window, $0.72 \mathrm{~m}$ wide $\times 1.0 \mathrm{~m}$ long, was on the west side. One air conditioning with a capacity of $9500 \mathrm{Btu} / \mathrm{h}$ was installed and operated in each house.

\section{Temperature measurements}

The thermal effectiveness performance and temperature fluctuation of the four houses were studied over the period of $24 \mathrm{~h}$ of day-time and night-time conditions. The exterior and interior temperatures were measured by attaching the K-type thermocouples with an accuracy of $\pm 0.5 \%$ on both outer and inner surfaces of the four walls. The thermocouples were attached by aluminium foil tape to the wall surfaces to ensure good thermal contact. All temperature data were recorded at 5 min intervals using a data logger. The intensity of solar radiation and temperature in all positions were measured and recorded from 6 am of one day to 6 am of the following day, giving a $24 \mathrm{~h}$ test cycle. The cooling load of the air conditioning, which was with both the window and the door closed.

\section{RESULTS AND DISCUSSION}

\section{Compressive strength, density, water absorption, and thermal conductivity}

Black powder of $20 \%$ by weight, replacing the same amount of fine sand, was incorporated into the mixture of AAC to fabricate black powder AAC. The black powder AAC demonstrated the compressive strength of approximately 4.6 $\mathrm{MPa}$, which is higher than other reported concrete mixtures, including coal bottom ash $\left(2.78 \mathrm{~N} / \mathrm{mm}^{2}\right)$ [12], copper tailings and blast furnace slag $\left(4.00 \mathrm{~N} / \mathrm{mm}^{2}\right)$ [17], and high-calcium fly ash and natural zeolite (4.51 N/ $\mathrm{mm}^{2}$ ) [22]. Traditional AAC has a compressive strength of $4.0 \mathrm{~N} / \mathrm{mm}^{2}$ [25], and could achieve a higher value by incorporation more than $2 \%$ of other industrial waste products $[12,17,22,25]$. Incorporating the optimal content of black powder as an AAC component may result in the higher tobermorite phase proportion in AAC, which corresponded to the higher compressive strength [14]. The density and the water absorption of black powder AAC were $0.58 \mathrm{~g} / \mathrm{cm}^{3}$ and $0.43 \mathrm{~g} / \mathrm{cm}^{3}$, respectively. This density value was in the quality class basis of $4\left(0.51-0.80 \mathrm{~g} / \mathrm{cm}^{3}\right)$, 


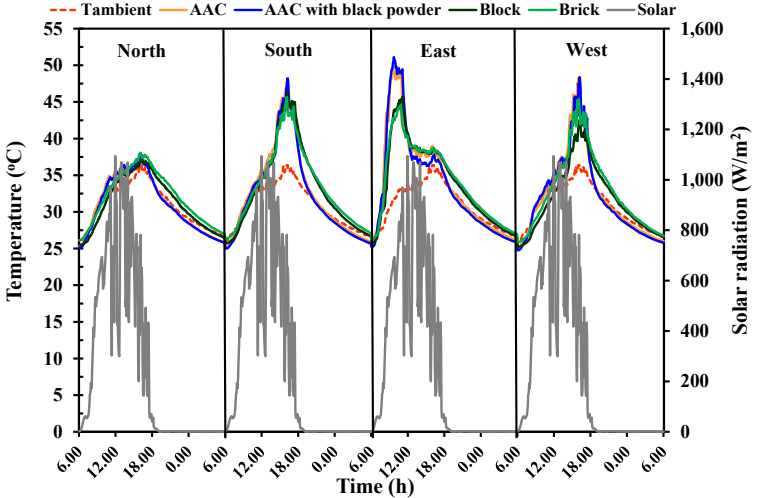

Fig. 1 Comparison of outer wall temperatures of the four houses.

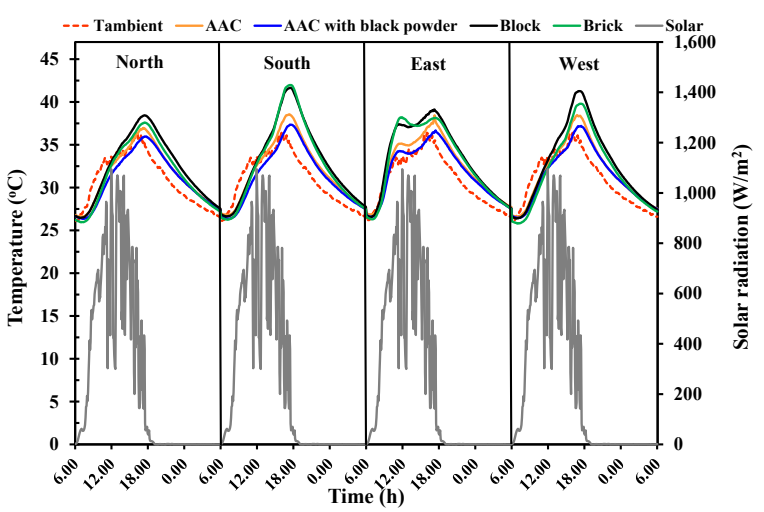

Fig. 2 Comparison of inner wall temperatures of the four houses.

according to TIS.1505-1998 of the Thai Industrial Standards Institute (TISI). Furthermore, the black powder AAC showed a low thermal conductivity of $0.140 \mathrm{~W} / \mathrm{m}^{\circ} \mathrm{C}$ that indicates an ability of thermal transmission prevention.

\section{Thermal effectiveness performance under natural weather conditions}

Figs. 1-4 show the results measured concurrently from the four houses built with different wall materials. The exterior and interior surface temperature evolution, heat flux, and room temperature of the four houses with no air conditioning were investigated and compared, and subsequent tests were done with the air conditioning operative.

\section{Exterior and internal surface temperature evolution of house wall}

The changes in solar radiation, ambient temperatures, and exterior and interior surface temperature evolution of the walls on each side of the houses are shown in Figs. 1-2. These tests were done and results were observed from 6 am of day to 6 am of the following day, giving a $24 \mathrm{~h}$ test cycle. The natural evaluation of solar radiation in the tropics appears due to periodical cloud cover that is typical between sunrise $(6.00 \mathrm{am})$ and sunset $(7.00 \mathrm{pm})$ with the maximum values of up to around $1.1 \mathrm{~kW} / \mathrm{m}^{2}$ around midday. Wind velocity around the testing area was between 0.30 and $2.54 \mathrm{~m} / \mathrm{s}$. The ambient temperature depended upon weather conditions and fluctuated between around $26^{\circ} \mathrm{C}$ in the morning between 5-6 am and up to the maximum value of around $36^{\circ} \mathrm{C}$ at around $5 \mathrm{pm}$.

\section{Northerly aspect wall surfaces}

At around $4 \mathrm{pm}$, the maximum northerly aspect exterior wall surface temperatures of the cement block, the brick, the AAC, and the black powder AAC houses were $37^{\circ} \mathrm{C}, 38^{\circ} \mathrm{C}, 38^{\circ} \mathrm{C}$, and $38^{\circ} \mathrm{C}$, respectively. On a similar order, the maximum interior wall surface temperatures, at around $5.30 \mathrm{pm}$, of the four houses were $38.5^{\circ} \mathrm{C}, 37.5^{\circ} \mathrm{C}, 37^{\circ} \mathrm{C}$, and $36^{\circ} \mathrm{C}$, respectively.

\section{Southerly aspect wall surfaces}

The south exterior wall surface temperatures of the four houses were similar throughout the morning and afternoon with the maximum $\sim 46^{\circ} \mathrm{C}$ at around $4 \mathrm{pm}$. Then, between $6 \mathrm{pm}$ and $5 \mathrm{am}$ of the following morning, the exterior wall surface temperature of the AAC and the black powder AAC houses cooled down to around $2-3^{\circ} \mathrm{C}$ lower than those of the cement block and the brick houses. At around $5.30 \mathrm{pm}$, the interior wall surface temperature of the cement block house reached the peak of $42^{\circ} \mathrm{C}$, while the temperatures of the brick, the AAC, and the black powder AAC were $41.5^{\circ} \mathrm{C}, 38.5^{\circ} \mathrm{C}$, and $37^{\circ} \mathrm{C}$, respectively.

\section{Easterly aspect wall surfaces}

The easterly aspect exterior wall surface temperature of the black powder AAC house rapidly rose to $51^{\circ} \mathrm{C}$ at around $9.30 \mathrm{am}$, while the peak temperatures of the AAC, the cement block, and the brick houses were $50^{\circ} \mathrm{C}$ at $\sim 9.30 \mathrm{am}, 46^{\circ} \mathrm{C}$ at $\sim 10.30 \mathrm{am}$, and $44^{\circ} \mathrm{C}$ at $\sim 11 \mathrm{am}$, respectively. At around $5.30 \mathrm{pm}$, the maximum interior wall surface temperature of the cement block house rapidly peaked as high as $39^{\circ} \mathrm{C}$, while the peak temperatures of the brick, the AAC, and the black powder AAC houses were $38^{\circ} \mathrm{C}, 37.5^{\circ} \mathrm{C}$, and $36.5^{\circ} \mathrm{C}$, respectively. 


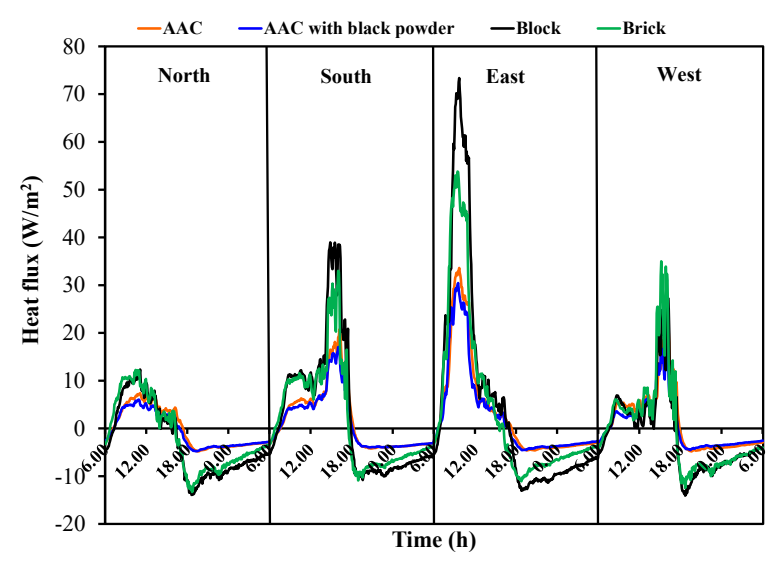

Fig. 3 Comparison of heat flux of the four houses.

\section{Westerly aspect wall surfaces}

For the west exterior wall surfaces, the maximum temperatures of the cement block, the brick, the AAC, and the black powder AAC houses were $42.5^{\circ} \mathrm{C}$ (at $3.30 \mathrm{pm}$ ), $45^{\circ} \mathrm{C}$ (at $4 \mathrm{pm}$ ), $48^{\circ} \mathrm{C}$ (at $4 \mathrm{pm}$ ), and $48.5^{\circ} \mathrm{C}$ (at $4 \mathrm{pm}$ ), respectively. At $5.30 \mathrm{pm}$, the maximum interior wall surface temperatures of the cement block, the brick, the AAC, and the black powder AAC were $41.5^{\circ} \mathrm{C}, 40^{\circ} \mathrm{C}, 38.5^{\circ} \mathrm{C}$, and $37^{\circ} \mathrm{C}$, respectively. The swing of the exterior and interior wall surface temperature on the four sides of individual houses depended upon the fluctuation of weather conditions at the test site (solar radiation intensity, wind velocity, relative humidity, etc.) which are in consistent with those previous reported $[8,9,15,25]$. The lowest interior wall surface temperature was observed on all sides of the black powder AAC house, compared with the other three houses. The reason could be due to the higher insulation property of the black powder incorporated AAC material not allowing the transmission of heat from the exterior to the interior of the wall.

\section{Comparison of flux evolution}

Fig. 3 shows the heat fluxes on both the interior and the exterior wall surfaces of the four houses. Heat flux of the wall surface is positive when heat waves propagate from the exterior surface, where the temperature is higher, to the interior surface of lower temperature. On the contrary, negative heat flux occurs when heat waves propagate from the higher temperature interior surface to the exterior surface of lower temperature $[15,25]$.

With the cement block house, positive heat fluxes of the north, south, east, and west wall surfaces were firstly increased and reached their maximum values of approximately $12,38,73$, and $27 \mathrm{~W} / \mathrm{m}^{2}$ at around $11 \mathrm{am}, 3-4 \mathrm{pm}, 9.30 \mathrm{am}$, and $4 \mathrm{pm}$, respectively; and as time went by, the values dropped. It was found that the negative heat fluxes of the four surfaces (on the same order: north, south, east, and west) began at around $4.30 \mathrm{pm}$, $6 \mathrm{pm}, 5 \mathrm{pm}$, and $5.30 \mathrm{pm}$ and reached the highest values at around $7 \mathrm{pm}, 7.30 \mathrm{pm}, 7 \mathrm{pm}$, and $6.30 \mathrm{pm}$ with the values of about $14,11,13$, and $14 \mathrm{~W} / \mathrm{m}^{2}$, respectively.

For the brick house, the maximum positive the heat flux values of the north, south, east, and west wall surfaces were observed at around $10.30 \mathrm{am}$, $4 \mathrm{pm}, 9.30 \mathrm{am}$, and $3 \mathrm{pm}$ with the values of 12 , 33, 54 , and $35 \mathrm{~W} / \mathrm{m}^{2}$, respectively; while the maximum negative values (on the same surface order) were found at around $6.30 \mathrm{pm}, 7 \mathrm{pm}, 7 \mathrm{pm}$, and $6.30 \mathrm{pm}$ with the values of about $13,11,11$, and $12.5 \mathrm{~W} / \mathrm{m}^{2}$, respectively.

For the heat fluxes of the AAC house walls, the maximum positive values of the north, south, east, and west surfaces were observed at around $11 \mathrm{am}$, $4 \mathrm{pm}, 9.30 \mathrm{am}$, and $4 \mathrm{pm}$; and the values were about $7.5,21,34$, and $20 \mathrm{~W} / \mathrm{m}^{2}$, respectively. The maximum negative values were about $5,4,4.5$, and $5 \mathrm{~W} / \mathrm{m}^{2}$ observed at around $7.30 \mathrm{pm}, 8.30 \mathrm{pm}$, $7.30 \mathrm{pm}$, and $7.30 \mathrm{pm}$, respectively.

For the heat fluxes of black powder AAC house walls, the maximum positive values of the north, south, east, and west surfaces were observed at around $11 \mathrm{am}, 4 \mathrm{pm}, 9.30 \mathrm{am}$, and $4 \mathrm{pm}$ with the values of $6,17,31$, and $18 \mathrm{~W} / \mathrm{m}^{2}$, respectively. The maximum negative heat flux values of the four surfaces were recorded at around $7.30 \mathrm{pm}, 8.30 \mathrm{pm}$, $7 \mathrm{pm}$, and $7.30 \mathrm{pm}$ with the values of $5,4,4.5$, and $4.5 \mathrm{~W} / \mathrm{m}^{2}$, respectively.

The aforementioned data show that all four sides of the black powder AAC house wall had the lowest maximum positive heat flux values, and all four sides of the cement block house wall had the highest maximum values. The maximum positive heat flux of the black powder AAC wall on the north, south, east, and west surfaces were less than the values of the AAC wall around 1.5, 4, 3, and $2 \mathrm{~W} / \mathrm{m}^{2}$; of the brick wall around $6,16,23$ and $17 \mathrm{~W} / \mathrm{m}^{2}$; and of the cement block wall around 6 , 21,42 , and $9 \mathrm{~W} / \mathrm{m}^{2}$, respectively.

The average positive heat flux values of the black powder AAC house on the north, south, east, and west surfaces were around 3.6, 6.9, 10.5, and $6.7 \mathrm{~W} / \mathrm{m}^{2}$, respectively. The average positive heat flux values of the commercial AAC wall surfaces 


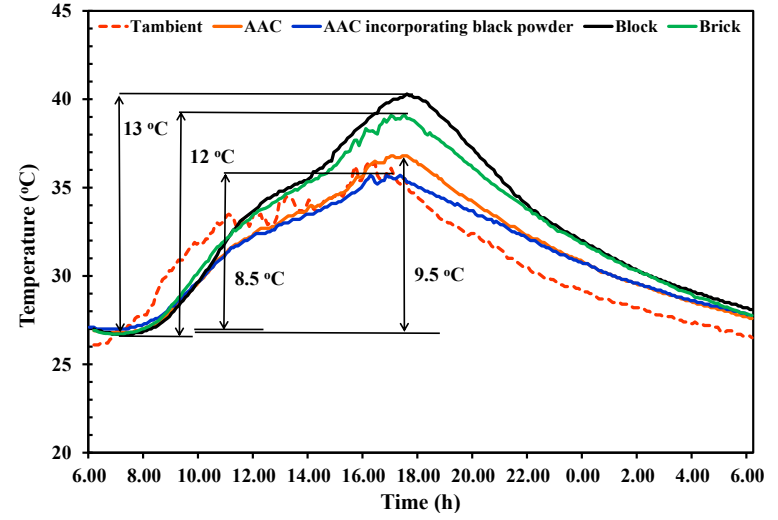

Fig. 4 Comparison of room temperature of the four houses.

were around $4.4,8.0,11.9$, and $7.0 \mathrm{~W} / \mathrm{m}^{2}$, respectively. For the cement block house walls, the values were around $6.2,15.7,24.7$, and $6.7 \mathrm{~W} / \mathrm{m}^{2}$, respectively; and for the brick house walls were around $6.5,12.2,21.9$, and $8.7 \mathrm{~W} / \mathrm{m}^{2}$, respectively. This demonstrates that utilization of black powder incorporated AAC as a building material can reduce the heat transfer through the building envelop and lead to an improvement in the insulation efficiency of buildings. With regard to cooling load and power consumption measurements, the heat transfer improvement achieved nearly 50\% reduction similar to previously reported data $[10,15]$. This is clearly a significant result.

\section{Comparison of room temperatures}

Room temperatures in the four houses between 6 am and $6 \mathrm{pm}$ are shown in Fig. 4. The effect of the fluctuating nature of solar radiation, ambient temperature, heat flux transfer, and exterior and interior surface temperature evolution of the individual houses walls on their room temperatures varied over the day. It can be seen that the room temperatures of the four houses were similar between 6 am and $10.30 \mathrm{am}$. Thereafter, the houses reached different peak temperatures at different times. By $11 \mathrm{am}$, the room temperature of black powder AAC house was between $1{ }^{\circ} \mathrm{C}$ and $4.5^{\circ} \mathrm{C}$ lower than the other three houses. After $11 \mathrm{am}$, the temperature readings diverged. The room temperature of the cement block house rose rapidly and achieved the peak value, the highest compared with the other houses, of $41^{\circ} \mathrm{C}$ at about $6 \mathrm{pm}$. The room temperature of the brick house peaked at $39^{\circ} \mathrm{C}$ at about $5 \mathrm{pm}$. The AAC house had the slowest temperature rise. At $5 \mathrm{pm}$, the AAC house reached its peak temperature

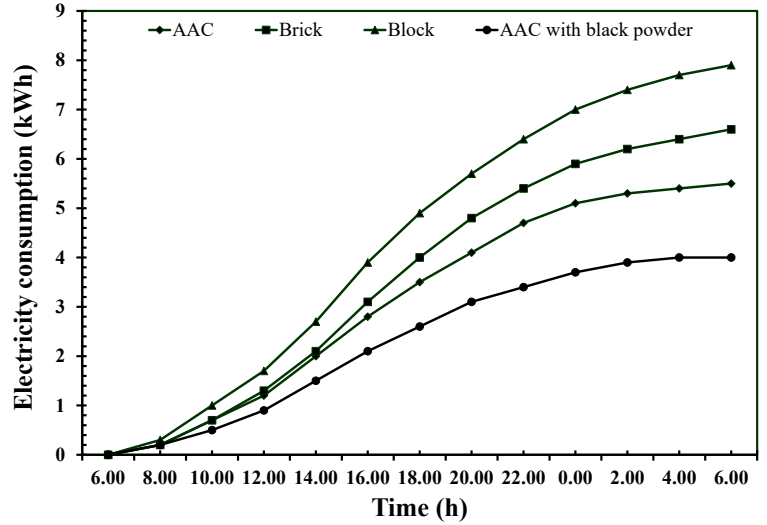

Fig. 5 Comparison of the cooling load of air condition in each house for $24 \mathrm{~h}$.

of $36.5^{\circ} \mathrm{C}$, and the black powder AAC house showed the lowest peak temperature, $35.5^{\circ} \mathrm{C}$.

These observed data indicate that the utilization of black powder incorporated AAC material significantly attenuates the daily room temperature fluctuation of partitions. The daily room temperature swing was reduced from $13^{\circ} \mathrm{C}$ (cement block house), $12{ }^{\circ} \mathrm{C}$ (brick house), and $9.5^{\circ} \mathrm{C}$ (commercial AAC house) to only $8.5^{\circ} \mathrm{C}$ in the black powder AAC house. When the ambient temperature was compared against the room temperatures of the four houses, it was found that room temperatures of the cement block and the brick houses were lower than the ambient temperature between 7 am and midday, i.e., a $5 \mathrm{~h}$ period; while the room temperatures of the AAC house was lower than the ambient temperature between 7 am and $3 \mathrm{pm}$, i.e., an $8 \mathrm{~h}$ period. Interestingly, the black powder AAC house showed a lower room temperature than the ambient temperature for $9 \mathrm{~h} 30 \mathrm{~min}$ from $7 \mathrm{am}$ to $4.30 \mathrm{pm}, 1 \mathrm{~h} 30$ min longer than the AAC house and $4 \mathrm{~h} 30$ min longer than the cement block and the brick houses This result clearly demonstrated the benefit of black powder incorporation on insulation efficiency. It has been reported that incorporating black powder into the AAC can contribute to reduction of temperature in a room, energy saving in buildings, and a significant reduction in the yearly peak cooling requirement $[9,15,25]$.

\section{Comparison of cooling load}

The cooling load on the air conditioners in the four houses was measured and compared. The measurements are shown in Fig. 5. All the houses were tested first with closed windows and doors for $24 \mathrm{~h}$ (from $6 \mathrm{am}$ to $6 \mathrm{am}$ ). It was found that the 
cooling load in the cement block wall house started to increase the soonest, and continued to increase over the $24 \mathrm{~h} 6 \mathrm{am}$ to $6 \mathrm{am}$. The cooling load on the air conditioner in the block house was around $7.9 \mathrm{kWh}$ of electrical consumption. The cooling load in the brick, AAC, and black powder incorporated AAC houses had a similar trend to the cement block wall house. At the end of the $24 \mathrm{~h}$ period, the cooling loads in the brick, AAC, and black powder incorporated AAC houses were around 6.6, 5.5, and $4.1 \mathrm{kWh}$ of electrical consumption, respectively. The results indicated that black powder AAC house, compared with the AAC, the brick, and the cement block houses, could save the electrical consumption approximately $25.5 \%, 37.9 \%$, and $48.1 \%$ respectively. The reduction of cooling load reflects the high insulation efficiency of the black powder, which is in agreement with previous studies $[8,9,14]$. Again, this demonstrates the ability of the black powder incorporation to significantly reduce the cooling load and electrical consumption of air conditionings. Hence, incorporated AAC could be seriously considered as an important adjunct component in construction materials.

\section{CONCLUSION}

The incorporation of black powder in the ACC mix can reduce the heat wave propagation through the building envelope and, therefore, the interior spaces, leading to an improvement in the insulation efficiency of buildings. The conservation of electrical power consumption of the cooling load on air conditioning in the house with black powder AAC walls was achieved, and the power consumption was saved approximately $25.5 \%, 37.9 \%$, and $48.1 \%$ compared with those of commercial AAC, brick, and cement block, respectively. The results showed that energy can be saved by the recovery of heat insulation due to incorporation of black powder into the AAC. The effectiveness of black powder AAC has been clearly demonstrated in terms of thermal effectiveness and power consumption reduction. Therefore, black powder is highly recommended as an adjunct material in concrete and construction materials in the future.

\section{Appendix A. Supplementary data}

Supplementary data associated with this article can be found at http://dx.doi.org/10.2306/ scienceasia1513-1874.2021.S015.

Acknowledgements: The authors would like to thank the Thailand Science Research and Innovation (TSRI),
Faculty of Science, Naresuan University for providing financial support to this research work, and our research center. Thanks are given to Mr. Roy I. Morien of the Naresuan University Graduate School for editing this document.

\section{REFERENCES}

1. Ürge-Vorsatz D, Cabeza LF, Serrano S, Petrichenko $\mathrm{K}$ (2015) Heating and cooling energy trends and drivers in buildings. Renew Sustain Energy Rev 41, 85-98.

2. Ürge-Vorsatz D, Petrichenko K, Staniec M, Eom J (2013) Energy use in buildings in a long-term perspective. Curr Opin Environ Sustain 5, 141-151.

3. Kamma J, Manomaiphiboon K, Aman N, Thongkamdee T, Chuangchote S, Bonnet S (2020) Urban heat island analysis for Bangkok: multi-scale temporal variation, associated factors, directional dependence, and cool island condition. ScienceAsia 46, 213-223.

4. Chan ALS, Chow TT (2013) Evaluation of overall thermal transfer value (OTTV) for commercial buildings constructed with green roof. Appl Energy 107, $10-24$.

5. Yang LJ, Yang EH (2016) Energy performance of building envelopes integrated with phase change materials for cooling load reduction in tropical Singapore. Appl Energy 162, 207-217.

6. Mano C, Thongtha A (2021) Enhanced thermal performance of roofing materials by integrating phase change materials to reduce energy consumption in buildings. J Renew Mater 9, 495-506.

7. Nahar NM, Sharma P, Purohit MM (2003) Performance of different passive techniques for cooling of buildings in arid regions. Build Environ 38, 109-116.

8. Thongtha A, Boontham P (2020) Experimental investigation of natural lighting systems using cylindrical glass for energy saving in buildings. Energies 13, ID 2528.

9. Thongtha A, Khongthon A, Boonsri T, Chan HY (2020) Thermal effectiveness enhancement of autoclaved aerated concrete wall with PCM-contained conical holes to reduce the cooling load. Mater 12, ID 2170.

10. Tao HS (2004) Research for developing aerated concrete by using fly ash with high calcium of Gehua power plant in Hongshan. PhD thesis, Wuhan Univ of Technology, WuHan, China.

11. Koronthalyova O (2011) Moisture storage capacity and microstructure of ceramic brick and autoclaved aerated concrete. Constr Build Mater 25, 879-885.

12. Kurama H, Topcu IB, Karakurt C (2009) Properties of the autoclaved aerated concrete produced from coal bottom ash. J Mater Process Technol 209, 767-773.

13. Cai LX, Ma BG, Li XG, Yang L, Liu ZL, Jian SW (2016) Mechanical and hydration characteristics of 
autoclaved aerated concrete (AAC) containing irontailings: Effect of content and fineness. Constr Build Mater 128, 361-372.

14. Thongtha A, Maneewan S, Punlek C, Ungkoon Y (2014) Investigation of the compressive strength, time lags and decrement factors of AAC-lightweight concrete containing sugar sediment waste. Energy Build 84, 516-525.

15. Punlek C, Maneewan S, Thongtha A (2017) Phase change material coating on autoclaved aerated lightweight concrete for cooling load reduction. Mater Sci 23, 145-149.

16. Topcu IB, IsÄśkdag B (2008) Effect of expanded perlite aggregate on the properties of lightweight concrete. J Mater Process Tech 204, 34-38.

17. Huang XY, Ni W, Cui WH, Wang ZJ, Zhu LP (2012) Preparation of autoclaved aerated concrete using copper tailings and blast furnace slag. Constr Build Mater 27, 1-5.

18. Mostafa NY (2005) Influence of air-cooled slag on physicochemical properties of autoclaved aerated concrete. Cement Concr Res 35, 1349-1357.

19. Ma BG, Zheng X (1999) Study on a new kind of aerated concrete containing efflorescence sand- phosphorus slag-lime. $J$ Build Mater 2, 223-228.

20. Li FX, Chen YZ, Long SZ (2008) Experimental investigation on aerated concrete with addition of lead-zinc tailings. J Southwest Jiaotong Univ 43, 810-815.

21. Wang Y, Yin J, Chen JC, Peng CQ (2000) Aerocrete made with low silicon tailings of Cheng Chao iron ore mine. J Wuhan Univ Tech Mater Sci Ed 15, 58-62.

22. Jitchaiyaphum K, Sinsiri T, Jaturapitakkul C, Chindaprasirt P (2013) Cellular lightweight concrete containing high-calcium fly ash and natural zeolite. Int $J$ Miner Metal Mater 20, 462-471.

23. Wang QK, Chen YZ, Li FX, Sun T, Xu BB (2006) Microstructure and properties of silty siliceous crushed stone-lime aerated concrete. $J$ Wuhan Univer Tech Mater Sci Ed 21, 17-20.

24. International Organization of Motor Vehicle Manufacturers (2017) 2016 Production Statistics, OICA, France. Available at: http://www.oica.net/category/ production-statistics/2016-statistics/.

25. Maneewan S, Janyoosuk K, Chan HY, Thongtha A (2019) Incorporating black dust into autoclaved aerated concrete wall for heat transfer reduction. $J$ Metals Mater Miner 29, 82-87. 
Appendix A. Supplementary data

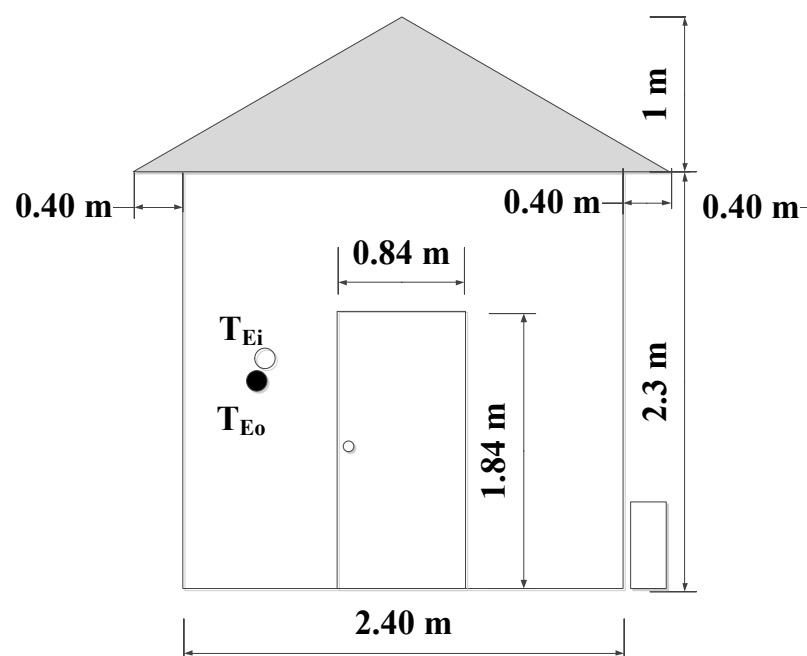

East side

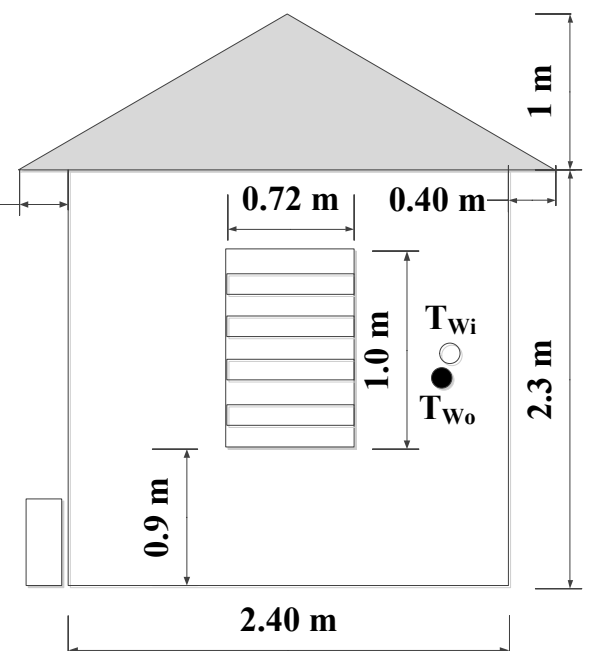

West side
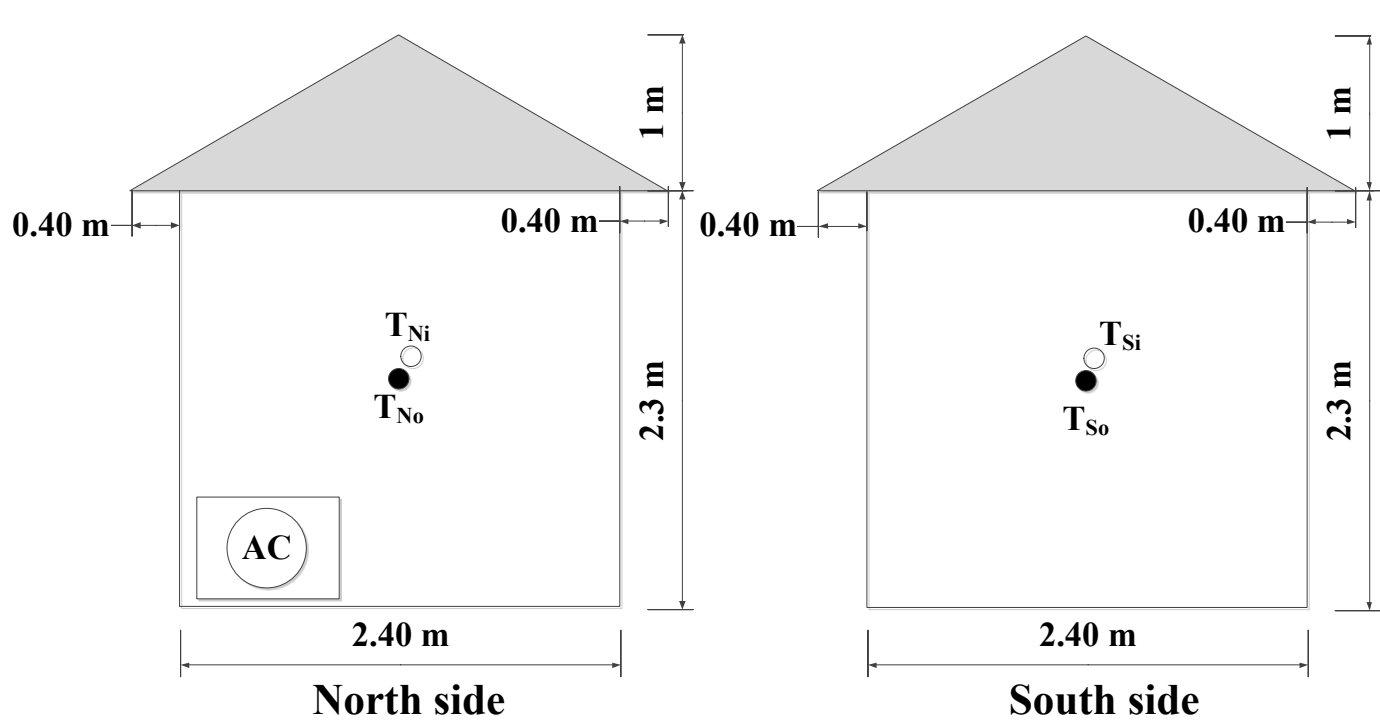

South side

Fig. S1 Dimensions of the four houses and the installation positions of the thermocouples. 